\title{
Recombinant Lines Obtained from an Interspecific Cross between Lycopersicon Species Selected by Fruit Weight and Fruit Shelf Life
}

\author{
Gustavo R. Rodríguez ${ }^{1}$ and Guillermo R. Pratta ${ }^{1}$ \\ Consejo Nacional de Investigaciones Científicas y Técnicas (CONICET). Cátedra de Genética, \\ Facultad de Ciencias Agrarias, Universidad Nacional de Rosario, CC 14 S2125ZAA, Rosario, Santa \\ $\mathrm{Fe}$, Argentina
}

\author{
Roxana Zorzoli', 2 and Liliana A. Picardi \\ Consejo de Investigaciones de la Universidad Nacional de Rosario (CIUNR). Cátedra de Genética, \\ Facultad de Ciencias Agrarias, Universidad Nacional de Rosario, CC 14 S2125ZAA, Rosario, Santa \\ $\mathrm{Fe}$, Argentina
}

\begin{abstract}
ADDITIONAL INDEX WORDs. divergent-antagonistic selection, Lycopersicon esculentum, Lycopersicon pimpinellifolium, random drift, tomato breeding

Abstract. A cross was performed between Lycopersicon esculentum Mill. 'Caimanta' and L. pimpinellifolium (Jusl.) Mill. accession LA722. Divergent-antagonistic selection for fruit weight and shelf life started in the $F_{2}$ generation. Fruit shelf life showed transgressive segregation in this $F_{2}$ generation. The selection process continued until the $F_{6}$ generation, but we found that only fruit weight was responsive to selection. Seventeen recombinant lines (RILs) were analyzed for both traits. Nine of these RILs were obtained by the selection process. The other eight RILs were obtained by selfing without selection from the same $\mathrm{F}_{2}$ generation to assess random drift. Highly significant differences were found among these RILs for both fruit weight and shelf life. Random drift was as important as selection in producing different genotypes. Although fruit shelf life showed null response to selection in this interspecific cross, selfing and selecting has generated a new population of 17 recombinant genotypes for both fruit weight and shelf life. This experiment has demonstrated that wild tomato species offer breeders another possibility to enhance the genetic variability for fruit shelf life and fruit weight in tomato germplasm.
\end{abstract}

Reduced levels of genetic variation can be seen in tomato cultivars compared with their wild relatives, specially in self-pollinated crops (Miller and Tanskley, 1990). One way to increase genetic variation and potentially boost performance of cultivars is by tapping into the vast reservoir of novel alleles found in wild germplasm (Tanskley and McCouch, 1997). The wild relatives of crop species often carry hidden alleles, which may not be phenotypically obvious, but can be effectively introduced into elite cultivars for improving performance (de Vicente and Tanskley, 1993; Foolad et al., 2002).

For example, single locus mutants producing long-shelf-life fruit have been identified within the tomato gene pool. Mutants, such as rin (ripening inhibitor), nor (nonripening), $\mathrm{Nr}$ (never ripe), and alc (alcobaca), drastically change fruit quality. They do extend fruit shelf life, but show pleiotropic effects on carotenoid synthesis and other ripening processes that reduce overall fruit quality (Moore et al., 2002; Mutschler et al., 1992; Ng and Tigchelaar, 1977; Thompson et al., 1999).

Wild species of Lycopersicon Mill. have been extensively used as sources of disease resistance and enhanced nutritional quality (Fulton et al., 2002; Rick, 1979). Contributions from wild tomato germplasm to fruit shelf life in commercial variaties remain unexploited. The cultivar Caimanta is a standard Argentinean cultivar frequently used in Argentina. This genotype has very

Received for publication 16 Dec. 2005. Accepted for publication 17 May 2006. The cost of publishing this article was financed by a grant from ANPCyT (SECyT, Argentina) to G.R.P.

'These authors contributed equally to this work.

${ }^{2}$ To whom reprint requests should be addressed. E-mail address: rzorzoli@unr. edu.ar good acceptance in fresh-market tomato in spite of not having long fruit shelf life. On this point, both Pratta et al. (1996) and Zorzoli et al. (1998) have reported that some lines of L.esculentum var. cerasiforme (Dum.) Gray and L. pimpinellifolium, as well as their respective hybrids with L. esculentum, had longer shelf life than some commercial cultivars. In a search for an appropiate tomato genotype for breeding all production traits simultaneously, Pratta et al. (2003) studied the genetic contributions from L. esculentum var. cerasiforme accession LA1385, L. pimpinellifolium accession LA722, and L. esculentum 'Caimanta'. The contributions of parental lines were then also compared with nor and rin mutations in both the homozygous and the heterozygous states. Pratta's study concluded that the $\mathrm{F}_{1}$ (L. esculentum 'Caimanta' $x$ L. pimpinellifolium accession LA722) appears to be the most promising tomato hybrid cross for overall fruit quality improvement, since its parents had the largest differences in allele frequencies and the greatest genetic divergence. Following Pratta's work, our objective was to develop tomato genotypes divergent for fruit weight and fruit shelf life starting from an interspecific cross between L. esculentum 'Caimanta' and L. pimpinellifolium accession LA722.

\section{Materials and Methods}

Plant materials. Experiments were carried out at the experimental field J.F. Villarino, Facultad de Ciencias Agrarias, Universidad Nacional de Rosario, located at Zavalla, Argentina (lat. $33^{\circ} \mathrm{S}$, long. $61^{\circ} \mathrm{W}$ ). A small-fruited (mean fruit weight, $0.80 \mathrm{~g}$ ) of the wild tomato species L. pimpinellifolium accession LA722 was crossed as the male parent to the large-fruited inbred 
L. esculentum 'Caimanta' (mean fruit weight, $84.05 \mathrm{~g}$ ). It was noted in previous experiments that fruit shelf life was $18.64 \mathrm{~d}$ for LA722 and 7.44 d for 'Caimanta' (Zorzoli et al., 2000). Lycopersicon pimpinellifolium accession LA722 was provided by Tomato Genetic Resources Center (Davis, Calif.) and 'Caimanta' was provided by Germplasm Bank of Instituto Nacional de Tecnología Agropecuaria, located at Cerrillos (Salta, Argentina). The $\mathrm{F}_{1}$ hybrid was selfed to produce the $\mathrm{F}_{2}$ population. Plants of parental genotypes, $F_{1}$ and $F_{2}$ generations were obtained in seedling trays in August and 109 plants were transplanted to field in a completely randomized design after 1 month. Standard fertilization, irrigation, and pest and weed management practices were used (Ferratto et al., 1997). Following fruit ripening, a minimum sample of 10 breaker tomatoes was harvested from each plant (1153 total fruit were obtained from parental genotypes, $\mathrm{F}_{1}$ and $\mathrm{F}_{2}$ generations).

Traits evaluated. Fruit fresh weight was obtained at harvest [W (in grams)] and fruit shelf life [SL (in days)] was evaluated in each generation until $\mathrm{F}_{6}$ generation. Shelf-life trait was measured as the number of days elapsed from the harvesting until the first symptoms of deterioration and excessive softening appeared. To determine this trait the fruit were stored at $25^{\circ} \mathrm{C}$. Following the methodology of Buescher et al. (1976) and Schuelter et al. (2002) fruit were examined three times per week and those which were commercially unacceptable due to show some wrinkled areas or excessive softening were discarded.

Selection Process. Divergent-antagonistic selection for W and SL traits started in the $\mathrm{F}_{2}$ generation (Eisen, 1978) following the pedigree method (Hallauer, 1981). Four groups of $F_{2}$ plants were selected according to their position in the quadrants defined by the mean values for W and SL. Two groups were defined to obtain divergent fruit genotypes: Group I, high W and long SL $\left(\mathrm{W}^{+} \mathrm{SL}^{+}\right)$, and Group III, low W and short SL (W-SL-).The other two were chosen to obtain antagonistic genotypes: Group II, low $\mathrm{W}$ and long SL (W-SL+), and Group IV, high W and short $\mathrm{SL}\left(\mathrm{W}+\mathrm{SL}\right.$ ). Twenty-six $\mathrm{F}_{2}$ plants were selected: 11 plants corresponded to $\mathrm{F}_{3}$ families of Group I and the remaining groups had five $\mathrm{F}_{3}$ families each. Number of plants sown and transplanted to field (N), number of families (FL), and number of harvested fruit (n) in each selection cycle are shown in Table 1. In each selection cycle a completely randomized design was used. Nine lines were obtained by the selection process described before. At the $\mathrm{F}_{6}$ generation, the resulting genotypes were evaluated for $\mathrm{W}$ and SL, along and compared with eight additional unselected, selfed lines derived from the same interspecific cross.

Data analysis. The normal distribution of the W and SL was tested in each selection cycle according to the Shapiro and Wilk (1965) test. Mean values of both traits among parental genotypes and $F_{1}$ generation were compared by one-way analysis of variance (ANOVA). Degree of genetic determination (DGD) was evaluated in $\mathrm{F}_{2}$ generation to estimate genetic variance for both traits (Falconer and Mackay, 1996). The phenotypic correlation $\left(r_{\mathrm{P}}\right)$ between $\mathrm{W}$ and SL was calculated by Pearson coefficient in the $\mathrm{F}_{2}$ generation. Also genetic correlation $\left(\mathrm{r}_{\mathrm{G}}\right)$ was estimated through an analysis of covariance (ANCOVA) (Kearsey and Pooni, 1996). In order to estimate the narrow-sense heritability for $\mathrm{W}$ and $\mathrm{SL}$ traits, the offspring - parent regression $\left(\mathrm{b}_{\mathrm{F} 3, \mathrm{~F} 2}\right)$ was calculated between the $\mathrm{F}_{3}-\mathrm{F}_{2}$ generations. Response to selection (R) was evaluated within each group by differences between the mean $\mathrm{F}_{6}$ generation and the mean base population (Falconer and Mackay, 1996). In the $\mathrm{F}_{6}$ generation, genetic correlation between
Table 1. Number of plants sown and transplanted to the field, number of families and number of harvested fruit in each generation from cross between Lycopersicon esculentum 'Caimanta' and L. pimpinellifolium accession LA722.

\begin{tabular}{lccc}
\hline Generation & $\begin{array}{c}\text { Plant } \\
\text { sown } \\
\text { (no.) }\end{array}$ & $\begin{array}{c}\text { Families } \\
\text { (no.) }\end{array}$ & $\begin{array}{c}\text { Harvested } \\
\text { fruit } \\
\text { (no.) }\end{array}$ \\
\hline $\mathrm{F}_{2}$ & 88 & --- & 988 \\
$\mathrm{~F}_{3}$ & 282 & 26 & 4396 \\
$\mathrm{~F}_{4}$ & 223 & 27 & 2463 \\
$\mathrm{~F}_{5}$ & 208 & 21 & 2612 \\
$\mathrm{~F}_{6}$ & 152 & 17 & 2788 \\
\hline
\end{tabular}

$\mathrm{W}$ and SL traits was again estimated through an ANCOVA. Only the nine lines obtained by selection were used to estimate this genetic parameter. Finally, W and SL mean values of the 17 recombinant lines (RILs), L. esculentum 'Caimanta' and $L$. pimpinellifolium accession LA722 genotypes were compared by one-way ANOVA and Duncan's test $(P<0.05)$ was applied (Sokal and Rohlf, 1969).

\section{Results}

Selection Process. The tomato parental genotypes L. esculentum 'Caimanta' and L. pimpinellifolium accession LA722 had highly significant different fruit weight $(\mathrm{F}=333.6, P<0.0001)$. The $\mathrm{F}_{1}$ generation had an intermediate value between the parental genotypes $(\mathrm{W}=9.16 \mathrm{~g})$. The mean value in the $\mathrm{F}_{2}$ generation was $8.22 \mathrm{~g}$. The Shapiro-Wilk test revealed that W was not normally distributed in this generation. The transformation $\log _{10}$ improved normality and hence this transformation was used in the following analysis. The frequency distribution for $\mathrm{W}$ in the $\mathrm{F}_{2}$ generation is shown in Fig. 1A (nontransformed data).

Parental genotypes showed also significant differences for SL trait ( $\mathrm{F}=18.9, P<0.01)$, but in this case no significant difference was observed between the $F_{1}$ generation (19.34 d) and the wild parent LA722 ( $\mathrm{F}=0.2$, NS). Mean value of $\mathrm{F}_{2}$ generation was $20.23 \mathrm{~d}$. Again, the Shapiro-Wilk test showed that this trait was not normally distributed. The $\log _{10}$ was calculated and this transformation allowed obtaining the normal distribution for this trait. The frequency distribution in $\mathrm{F}_{2}$ generation for SLis shown in Fig. 1B (nontransformed data). It can be seen that a great number of $\mathrm{F}_{2}$ plants $(41.4 \%)$ had phenotypic mean values for SL higher than the mean value of LA722. It was found that DGD for W was $0.67 \pm 0.23$, but it was $0.23 \pm 0.02$ for SL. Thus, the genetic variability, estimated through DGD, was greater for $\mathrm{W}$ than for SL. Only $23 \%$ of the total variation of SL in $\mathrm{F}_{2}$ generation is attributable to genetic differences between individuals and $77 \%$ to nongenetic differences. Therefore, an important environmental component affects the expression of fruit shelf life.

Figure 2 shows the $\mathrm{F}_{2}$ plants that were assigned to different groups according to their $\mathrm{W}$ and SL phenotypic mean values. No significant phenotypic correlation was found between these two traits in the $\mathrm{F}_{2}$ generation $\left(\mathrm{r}_{\mathrm{P}}=0.07, \mathrm{NS}\right)$, but a significant genetic correlation was observed $\left(\mathrm{r}_{\mathrm{G}}=0.57, P<0.01\right)$, indicating that close linkage between these traits could be present.

The mean values and SE for W and SL traits in each $\mathrm{F}_{3}$ family are shown in Table 2. Family 1 had the greatest values for $\mathrm{W}$ $(20.15 \mathrm{~g})$ and SL (21.55 d). The smallest fruit weight $(2.81 \mathrm{~g})$ was observed in Family 18 and the shortest SL (9.98 d) was observed in Family 7. The narrow-sense heritability estimated in $\mathrm{F}_{3}-\mathrm{F}_{2}$ 

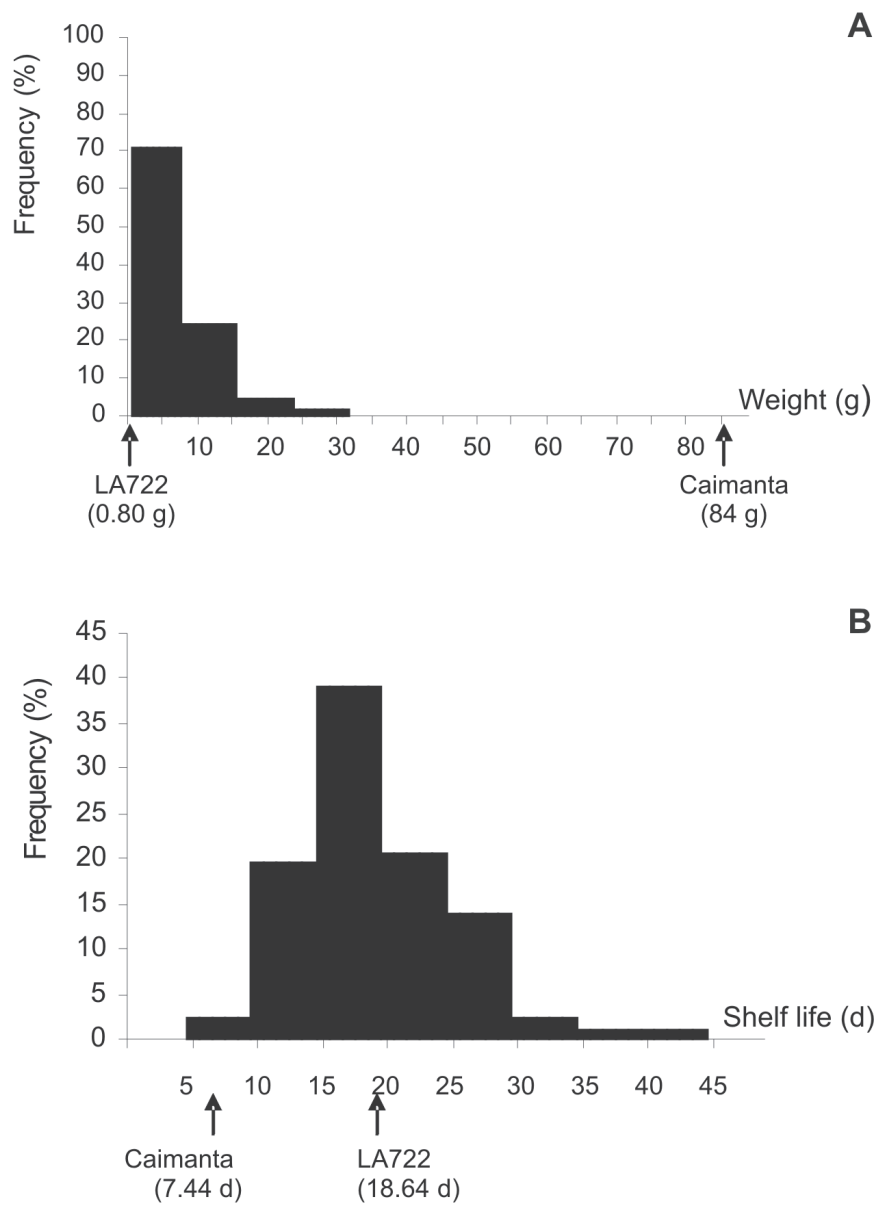

Fig. 1. Frequency distributions in the $\mathrm{F}_{2}$ generation from cross between Lycopersicon esculentum 'Caimanta' and L. pimpinellifolium accession LA722 for fruit weight (A) and fruit shelf life (B); nontransformed data.
A generations was $0.29 \pm 0.07(P<0.01)$ for $\mathrm{W}$, whereas it was no significant $(0.04 \pm 0.07, P>0.05)$ for SL. The $\mathrm{W}$ and SL mean values in the $\mathrm{F}_{4}$ and $\mathrm{F}_{5}$ families are also shown in Table 2 . The $\mathrm{F}_{4}$ families 18, 19 (Group III), and 12 (Group IV) were lost after transplantation to the field, while families 06 (Group II) and 20 (Group IV) did not produce enough fruit to continue the selection process. A few $\mathrm{F}_{5}$ families, 14b, 16b (Group II), and 27d (Group IV), were lost due to low viability of the seeds.

At the end of the selection scheme, nine lines were obtained (see Table 3) and named L1, L2, L3, L4, L5 (Group I), L6, L8 (Group II),L9, and L11 (Group III). No plants with the appropriate phenotype were available to continue the selection process for both traits in Group IV ( $\left.\mathrm{W}^{+} \mathrm{SL}^{-}\right)$. Response to selection for the W trait was: $7.71 \mathrm{~g}$ for Group I, $-3.75 \mathrm{~g}$ for Group II, and $-3.14 \mathrm{~g}$ for Group III. No response to selection was observed for SL trait in any group. The estimation of genetic correlation with the nine $\mathrm{F}_{6}$ lines obtained by selection was nonsignificant $\left(\mathrm{r}_{\mathrm{G}}=0.02\right)$.

EVALUATION OF THE SELECTED AND NONSELECTED RECOMBINANT LINES IN THE $\mathbf{F}_{6}$ GENERATION. The mean values of $\mathrm{W}$ and SL traits in both parents, in the nine $\mathrm{F}_{6}$ lines obtained by selection and in the eight $\mathrm{F}_{6}$ lines obtained by selfing from the same interspecific cross (a total of 17 RILs) are also shown in Table 3. There were significant differences for $\mathrm{W}(\mathrm{F}=479.8, P<0.01)$ and $\mathrm{SL}(\mathrm{F}=$ $22.2, P<0.01)$ among these 17 RILs.

It can be noted that the $\mathrm{L} 1$ genotype (selected for $\mathrm{W}^{+}$) and $\mathrm{L} 14$ genotype (obtained only by selfing) had the greatest values for fruit weight. The L6, L8, L9 and L11 genotypes (selected for Win GII and GIII) and L7, L10, L12, and L13 genotypes (obtained only by selfing) had the lowest values for $\mathrm{W}$ trait.

Regarding to SL, the L6 genotype had the greatest value, followed by L8 genotype (both lines were selected in the Group II for $\mathrm{SL}^{+}$). There was no difference between L15 and 'Caimanta' genotype. It can be noted that the L1 line (obtained by selection) was not significantly different when compared to L7 or L10 from the nonselected group.

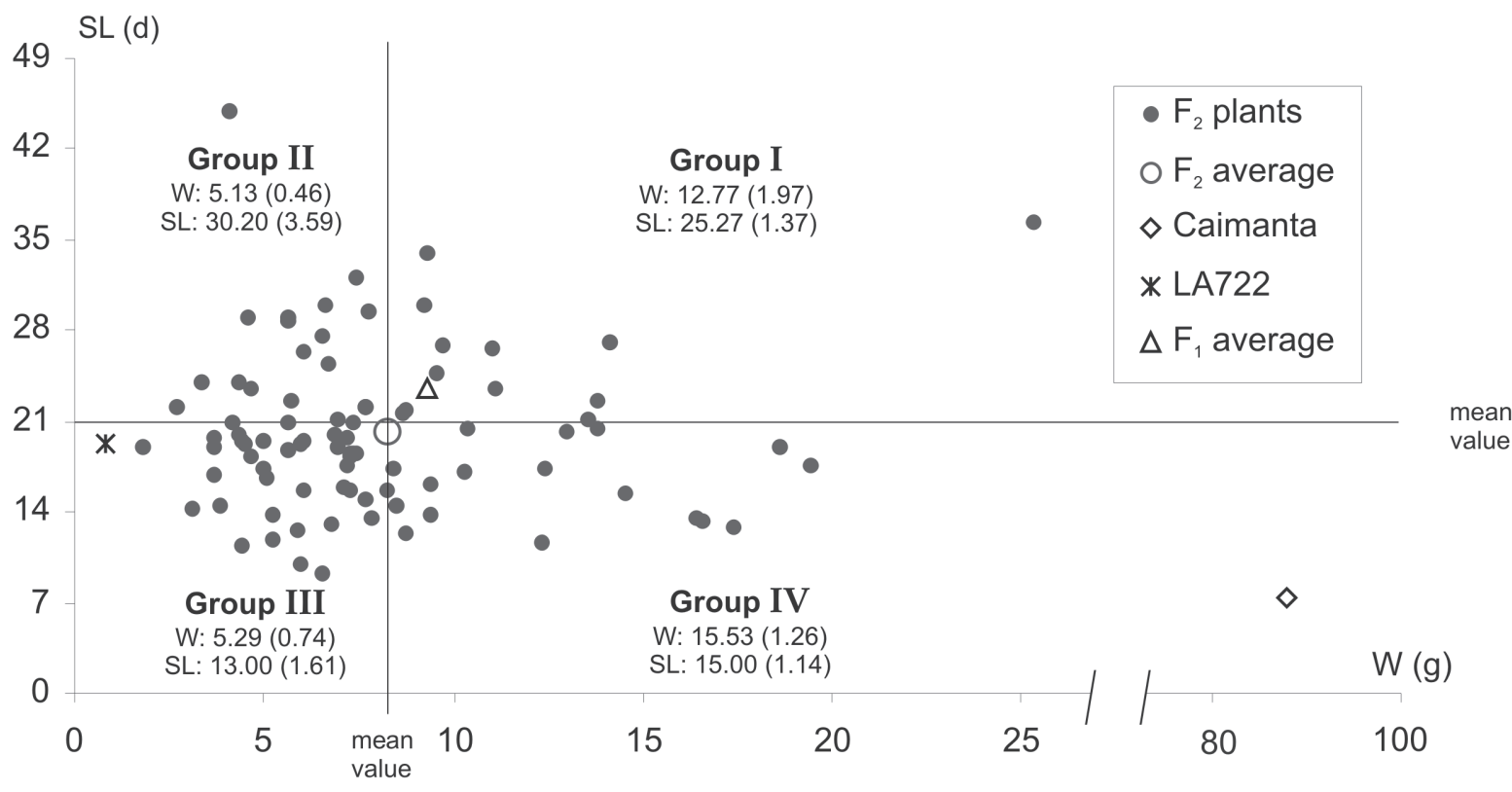

Fig. 2. Plants in $\mathrm{F}_{2}$ generation obtained from cross between Lycopersicon esculentum 'Caimanta' and L. pimpinellifolium accession LA722 accord to their mean values of fruit weight (W) and fruit shelf life (SL) belonging to different selection patterns. The mean values (SE in parenthesis) for both traits in each group are shown. 
Table 2. Means (SE in parenthesis) for fruit weight (W) and fruit shelf life (SL) in the $\mathrm{F}_{3}, \mathrm{~F}_{4}$, and $\mathrm{F}_{5}$ families from cross between Lycopersicon esculentum 'Caimanta' and L. pimpinellifolium accession LA722 for Group I [high W and long SL (W+SL+)], Group II [low W and long SL (W-SL+)], Group III [low W and short SL (W-SL-)], and Group IV [high W and short SL (W+SL-)].

\begin{tabular}{|c|c|c|c|c|c|c|c|c|c|}
\hline Group & $\mathrm{F}_{3}$ families & $\mathrm{W}(\mathrm{g})$ & SL (d) & $\mathrm{F}_{4}$ families & $\mathrm{W}(\mathrm{g})$ & SL (d) & $\mathrm{F}_{5}$ families & $\mathrm{W}(\mathrm{g})$ & SL (d) \\
\hline \multirow{12}{*}{ I } & & & & 44 & $11.41(0.68)$ & $32.60(1.68)$ & & & \\
\hline & 1 & $20.15(0.40)$ & $21.55(0.79)$ & 16 & $22.81(0.58)$ & $34.83(1.53)$ & $03 a$ & $18.59(1.13)$ & $18.22(0.89)$ \\
\hline & 2 & $6.13(0.38)$ & $14.92(0.70)$ & 17 & $9.96(0.28)$ & $14.10(0.72)$ & $04 \mathrm{a}$ & $13.19(0.87)$ & $16.58(0.67)$ \\
\hline & 3 & $10.52(0.42)$ & $11.65(0.77)$ & 32 & $5.65(0.62)$ & $12.61(1.53)$ & $05 \mathrm{a}$ & $6.32(0.88)$ & $17.35(0.70)$ \\
\hline & 4 & $6.95(0.32)$ & $15.30(0.59)$ & 22 & $5.21(0.21)$ & $11.88(0.51)$ & $06 \mathrm{a}$ & $7.91(0.93)$ & $14.52(0.72)$ \\
\hline & 5 & $6.82(0.45)$ & $14.66(0.82)$ & 35 & $5.19(0.15)$ & $11.19(0.38)$ & $07 \mathrm{a}$ & $5.63(0.77)$ & $14.46(0.60)$ \\
\hline & 6 & $7.19(0.22)$ & $14.97(0.41)$ & 20 & $4.13(0.18)$ & $9.73(0.44)$ & $08 \mathrm{a}$ & $9.77(1.25)$ & $16.89(1.02)$ \\
\hline & 7 & $9.13(0.33)$ & $9.98(0.61)$ & 08 & $6.42(0.26)$ & $9.98(0.64)$ & $09 \mathrm{a}$ & $8.51(1.10)$ & $20.41(0.87)$ \\
\hline & 8 & $6.56(0.38)$ & $12.11(0.72)$ & 24 & $6.28(0.16)$ & $12.88(0.41)$ & 010a & $10.55(1.38)$ & $18.79(1.07)$ \\
\hline & 9 & $4.31(0.48)$ & $17.76(0.91)$ & 40 & $5.79(0.18)$ & $12.96(0.45)$ & $011 \mathrm{a}$ & $6.10(0.98)$ & $15.73(0.75)$ \\
\hline & 10 & $5.91(0.20)$ & $12.23(0.37)$ & 43 & $5.03(0.24)$ & $9.19(0.59)$ & $012 \mathrm{a}$ & $8.34(0.78)$ & $17.26(0.61)$ \\
\hline & 11 & $7.16(0.31)$ & $12.03(0.56)$ & 45 & $3.53(0.28)$ & $8.08(0.69)$ & & & \\
\hline \multirow{5}{*}{ II } & 12 & $3.78(0.68)$ & $12.43(1.07)$ & 34 & $2.10(0.19)$ & $10.37(0.48)$ & $13 b$ & $3.26(1.32)$ & $11.02(1.01)$ \\
\hline & 13 & $3.73(0.43)$ & $15.66(0.80)$ & 23 & $1.20(0.58)$ & $6.52(1.42)$ & $14 \mathrm{~b}$ & & $11.02(1.01)$ \\
\hline & 14 & $3.71(0.42)$ & $14.04(0.79)$ & 21 & $2.32(0.21)$ & $9.72(0.52)$ & $15 \mathrm{~b}$ & $4.26(0.97)$ & $22.40(0.74)$ \\
\hline & 15 & $6.69(0.25)$ & $14.54(0.48)$ & 06 & y & y & $16 \mathrm{~b}$ & & \\
\hline & 16 & $4.27(0.38)$ & $14.00(0.71)$ & 10 & $2.27(0.40)$ & $11.89(0.98)$ & $17 \mathrm{~b}$ & $5.05(1.11)$ & $17.84(0.85)$ \\
\hline \multirow{5}{*}{ III } & 17 & $3.35(0.21)$ & $12.02(0.39)$ & 38 & $3.81(0.20)$ & $9.72(0.50)$ & & & \\
\hline & 18 & $2.81(0.26)$ & $11.40(0.47)$ & 01 & $2.44(0.21)$ & $7.36(0.53)$ & $18 \mathrm{c}$ & $4.23(1.59)$ & $14.61(1.19)$ \\
\hline & 19 & $4.26(0.34)$ & $11.62(0.62)$ & 02 & $1.83(0.68)$ & $10.53(1.68)$ & $19 \mathrm{c}$ & $2.38(2.28)$ & $10.73(1.74)$ \\
\hline & 20 & $6.35(0.33)$ & $10.43(0.62)$ & 18 & $\mathrm{z}$ & z & $20 \mathrm{c}$ & $3.69(0.90)$ & $15.58(0.70)$ \\
\hline & 21 & $6.02(0.54)$ & $18.60(1.02)$ & 19 & z & z & & & \\
\hline \multirow{5}{*}{ IV } & 22 & $4.61(0.32)$ & $18.90(0.59)$ & 01 & $7.58(0.94)$ & $12.25(2.29)$ & & & \\
\hline & 23 & $10.55(0.35)$ & $11.83(0.65)$ & 09 & $4.03(0.88)$ & $9.63(2.29)$ & $23 d$ & $2.90(1.11)$ & $17.90(0.83)$ \\
\hline & 24 & $7.02(0.27)$ & $11.10(0.50)$ & 12 & z & z & $26 \mathrm{~d}$ & $6.50(1.44)$ & $10.20(1.11)$ \\
\hline & 25 & $6.68(0.43)$ & $14.34(0.79)$ & 16 & $3.97(0.42)$ & $9.25(1.03)$ & $27 d$ & & \\
\hline & 26 & $7.86(0.27)$ & $12.42(0.49)$ & 20 & y & $\mathrm{y}$ & & & \\
\hline
\end{tabular}

¿Lost families.

yFamilies producing few fruit.

\section{Discussion}

The results for fruit weight in the $\mathrm{F}_{1}$ and $\mathrm{F}_{2}$ generations are consistent with classical studies in which $\mathrm{F}_{1}$ hybrids, resulting from a cross between a large and small-fruited cultivar, typically exhibit weights similar to that of the smaller fruit parent (MacArthur and Butler, 1938). It has been postulated that small fruit alleles are semidominant to large fruit alleles, which may explain the skewed distribution toward the small fruit size that was observed in this study. Weller et al. (1988) found that in wild species L. pimpinellifolium there are polygenes with dominant effects that cause a reduction in fruit weight. More recently, Grandillo et al. (1999) postulated that the alleles for low fruit weight are semidominant over the alleles for high fruit weight. Molecular marker studies conducted by Paterson et al. (1991) found 11 QTLs affecting tomato fruit weight in a cross between the domesticated tomato and the related wild tomato species, $L$. cheesmanii Riley. In all cases, the wild species alleles caused a reduction in fruit weight. Other molecular marker studies identified a major fruit weight QTL ( $f w 2.2)$ on chromosome 2 present in wild species and absent in cultivated tomato by a major allelic substitution at fw2.2 (Alpert and Tanksley, 1996). Such a finding could explain the genic action of partial dominance that would have caused a smaller fruit size in the $F_{1}$ generation, similar to the LA722 wild parent.

For SL, a great number of $\mathrm{F}_{2}$ tomatoes had phenotypic mean values more extreme than LA722. This result could indicate the presence of a transgressive inheritance for this trait. Exotic genes from the wild tomato parent could have a genetic contribution to SL, which differs to the rin, nor, and alc mutants identified within the cultivated tomato gene pool. Nevertheless, both $L$. pimpinellifolium accession LA722 and L. esculentum 'Caimanta' may carry polygenes with positive and negative effects on the expression of this trait, whose segregation and recombination would be responsible for the transgressive variation. A wide genetic variability was found for both traits among and within the $\mathrm{F}_{3}$ families. As in all of the self-pollinated crops, the selection process was accompanied by a dispersion of the genic frequency (a random drift effect) producing a redistribution of genetic variance in both traits. In the $\mathrm{F}_{5}$ generation there were no plants in Group IV with high $\mathrm{W}$ and short SL, therefore selection was not made within that group. It is a known fact that if the frequencies of some genes are very low, they will be included in some samples derived from the initial population, but they would be absent from others (Kearsey and Pooni, 1996). The estimated additive genetic variance was null for fruit shelf life. Clearly, this parameter showed that the total phenotypic variation among selected families is nonheritable. These results, as well as others in previous reports (Pratta et al., 2000), allowed us to postulate the hypothesis that $\mathrm{SL}$ is a trait mainly determined by few genes with major effect, i.e., the wild LA722 parent is carrier of dominant alleles that prolongs SL. A great number of individuals with extreme values for SL were observed not only in the $\mathrm{F}_{2}$ generation, but during the whole selection process. Thus, in group II L6 and L8 genotypes 
Table 3. Means and SE for fruit weight (W) and fruit shelf life (SL) for Lycopersicon esculentum 'Caimanta', L. pimpinellifolium accession LA722, and the 17 recombinant $\mathrm{F}_{6}$ lines.

\begin{tabular}{lccr}
\hline & Genotype & $\mathrm{W}(\mathrm{g})$ & \multicolumn{1}{c}{ SL $(\mathrm{d})$} \\
\hline \multirow{2}{*}{ Parents: } & Caimanta & $98.48(9.87) \mathrm{a}^{\mathrm{z}}$ & $9.74(0.91) \mathrm{k}$ \\
& LA722 & $0.87(0.02) \mathrm{h}$ & $15.67(0.37) \mathrm{ij}$ \\
\hline
\end{tabular}

\begin{tabular}{|c|c|c|c|c|}
\hline & \multirow{5}{*}{$\begin{array}{c}\text { Group } \\
\mathrm{I}^{\mathrm{y}}\end{array}$} & L1 & $27.24(0.67) b$ & $21.24(0.60) \mathrm{d}-\mathrm{f}$ \\
\hline \multirow{4}{*}{$\mathrm{F}_{6}$ Lines } & & $\mathrm{L} 2$ & $19.25(0.74) \mathrm{cd}$ & $21.94(0.82) \mathrm{de}$ \\
\hline & & L3 & $20.29(0.68) \mathrm{c}$ & $25.00(0.91) \mathrm{c}$ \\
\hline & & L4 & $18.82(0.51) \mathrm{de}$ & $16.59(0.53) \mathrm{h}-\mathrm{j}$ \\
\hline & & L5 & $8.34(0.37) \mathrm{f}$ & $17.26(0.69) \mathrm{h}-\mathrm{j}$ \\
\hline \multirow[t]{2}{*}{ selection: } & \multirow{2}{*}{ Group II } & L6 & $1.98(0.06) \mathrm{gh}$ & $31.28(1.95) \mathrm{a}$ \\
\hline & & L8 & $1.98(0.07) \mathrm{gh}$ & $28.22(1.67) b$ \\
\hline
\end{tabular}

\begin{tabular}{clll} 
Group & L9 & $2.13(0.05) \mathrm{gh}$ & $14.96(0.49) \mathrm{j}$ \\
III & L11 & $3.26(0.13) \mathrm{g}$ & $18.70(1.16) \mathrm{f}-\mathrm{i}$ \\
\hline
\end{tabular}

\begin{tabular}{llll} 
& L7 & $4.08(0.21) \mathrm{g}$ & $21.50(1.00) \mathrm{d}-\mathrm{f}$ \\
F 6 Lines obtained & L10 & $4.02(0.11) \mathrm{g}$ & $21.37(0.81) \mathrm{d}-\mathrm{f}$ \\
by selfing without & $\mathrm{L} 12$ & $3.23(0.08) \mathrm{g}$ & $20.39(0.92) \mathrm{d}-\mathrm{g}$ \\
\cline { 2 - 4 } selection: & $\mathrm{L} 13$ & $2.98(0.12) \mathrm{g}$ & $19.60(1.04) \mathrm{e}-\mathrm{h}$ \\
\cline { 2 - 4 } & $\mathrm{L} 14$ & $25.77(0.80) \mathrm{b}$ & $17.86(0.52) \mathrm{g}-\mathrm{j}$ \\
& $\mathrm{L} 15$ & $19.15(0.83) \mathrm{cd}$ & $11.32(0.67) \mathrm{k}$ \\
& $\mathrm{L} 16$ & $16.96(0.57) \mathrm{e}$ & $15.39(0.50) \mathrm{j}$ \\
& $\mathrm{L} 18$ & $18.15(0.54) \mathrm{de}$ & $23.12(0.72) \mathrm{cd}$ \\
\hline
\end{tabular}

$\overline{{ }^{2} \text { Different letters indicate significant differences }(P<0.05) \text { among }}$ genotypes according to Duncan's test.

yGroup I [high W and long SL (W+SL+)], Group II [low W and long SL (W-SL+)], Group III [low W and short SL (W-SL-)], Group IV [high W and short SL (W+SL-)].

showed maximal SL values. According to de Vicente and Tanksley (1993), crosses between cultivated and wild germplasm have great potential to generate new phenotypes that possess important traits for the adaptation to natural habitat as well as phenotypes with great agronomic values when the parental species have a high frequency of complementary alleles. It could be postulated that, in addition to be SL trait highly influenced by the environment, there would be some major inheritance genes involved on it. In consequence, random drift would have played a more important role than the selection process for this trait. It was an interesting fact that response to selection was only significant for $\mathrm{W}$ trait. These results confirmed that additive genetic variance was present only for this latter trait.

The estimated genetic correlation between $\mathrm{W}$ and SL traits in $\mathrm{F}_{2}$ was significant. However, when it was evaluated in the $\mathrm{F}_{6}$ lines obtained by divergent-antagonistic selection, this association disappeared. In fact, directed selection tends to modify the allelic frequency involved in the expression of the quantitative traits. Apparently, these results could support the conclusion that this selection process would have broken the linkage between the loci underlying W and SL traits. Nevertheless, selection and random drift together would have produced a change in the mean and the variance of both traits. As a consequence both processes would be responsible for the loss of the genetic association between these traits in $\mathrm{F}_{6}$ generation.

Mean fruit weight in the RILs was significantly smaller than in the L. esculentum 'Caimanta' parent. Nevertheless, a notable increase in fruit weight was observed if the wild parent had a mean value $<1 \mathrm{~g}$. Regarding the SL trait, it must be noted that 14 lines had phenotypic mean values more extreme than the wild parent. It could be concluded that these RILs have genic differences for these traits due to the combined effect of the selection and random drift.

Our results agree with Miller and Tanskley (1990) that only $<5 \%$ of the available genetic variation exists in tomato cultivars and the remainder is found in wild species of the genus. This interspecific cross, with subsequent selection and fixing of genes by random drift, has generated a new population of 17 recombinant genotypes for W and SL traits. This selection method, utilizing wild species as a parent, has proven to be useful to generate a new genetic variability that is available for tomato breeding programs.

\section{Literature Cited}

Alpert, K. and S.D. Tanksley. 1996. High-resolution mapping and isolation of a yeast artificial chromosome contig containing fw2.2: A major fruit weight quantitative locus in tomato. Proc. Natl. Acad. Sci. USA 93:15503-15507.

Buescher, R.W., W.A. Sistrunk, E.C. Tigchelaar, and T.J. Ng. 1976. Softening, pectolytic activity and storage life of rin and nor tomato hybrids. HortScience 11:603-605.

de Vicente, M.C. and S.D. Tanskley. 1993. QTLanalysis of transgressive segregation in an interspecific tomato cross. Genetics 134:585-596.

Eisen, E.J. 1978. Single-trait and antagonistic index selection for litter size and body weight in mice. Genetics 88:781-811.

Falconer, D.S. and T.F.C. Mackay. 1996. Introduction to quantitative genetics. 4th ed. Longman Group, Edinburgh Gate, England.

Ferratto, J.A., A. Longo, R. Grasso, M.C. Mondino, and A.C. Fernández. 1997. Ajuste del diagnóstico agronómico del Proyecto Hortícola Rosario. Publicación miscelánea Instituto Nacional de Tecnología Agropecuaria 32:1-48.

Foolad, M.R., L.P. Zhang, A.A. Khan, D. Nino-Liu, and G.L. Lin. 2002. Identification of QTLs for early blight, Alternaria solani resistance in tomato using backcross populations of a Lycopersicon esculentum $\times$ L. hirsutum cross. Theor. Appl. Genet. 104:945-958.

Fulton, T.M., P. Bucheli, E. Voirol, V. Petriard, and S.D. Tanksley. 2002. Quantitative trait loci, QTL affecting sugars, organic acids and other biochemical properties possibly contributing to flavor, identified in four advanced backcross populations of tomato. Euphytica 127:163-177.

Grandillo, S., H.M. Ku, and S.D. Tanksley. 1999. Identifying the loci responsible for natural variation in fruit and shape in tomato. Theor. Appl. Genet. 99:978-987.

Hallauer, A.R. 1981. Selection and breeding methods, p. 3-55. In: K.J. Frey (ed.). Plant breeding II. Iowa State Univ. Press, Ames.

Kearsey, M. and H. Pooni. 1996. The genetical analysis of quantitative traits. Chapman and Hall, Birmingham, U.K.

MacArthur, J.W. and L. Butler. 1938. Size inheritance and geometric growth processes in the tomato fruit. Genetics 23:253-268.

Miller, J.C. and S.D. Tanksley. 1990. RFLP analysis of phylogenetic relationship and genetic variation in the genus Lycopersicon. Theor. Appl. Genet. 80:437-448.

Moore S., J. Vrebalov, P. Payton, and J. Giovannoni. 2002. Use of genomics tools to isolate key ripening genes and analyse fruit maturation in tomato. J. Expt. Bot. 53:2023-2030.

Mutschler, M.A., D.W. Wolfe, E.D. Cobb, and K.S. Yourstone. 1992. Tomato fruit quality and shelf life in hybrids heterozygous for the alc ripening mutant. HortScience 27:352-355.

Ng, T.J. and E.C. Tigchelaar. 1977. Action of the nonripening (nor) mutant on fruit ripening of tomato. J. Amer. Soc. Hort. Sci. 102:504-509. 
Paterson, A.H., S. Damon, J.D. Hewitt, D. Zamir, H.D. Rabinowitch S.E. Lincoln, E.S. Lander, and S.D. Tanksley. 1991. Mendelian factors underlying quantitative traits in tomato: Comparison across species, generations, and environments. Genetics 127:181-197

Pratta, G., R. Zorzoli, and L.A. Picardi. 1996. Evaluación de caracteres de interés agronómico en especies del género Lycopersicon. Horticultura Argentina 15:25-32.

Pratta, G., R. Zorzoli, and L.A. Picardi. 2000. Interacciones genéticas entre germoplasma silvestre y cultivado de Lycopersicon spp. con efectos sobre la calidad del fruto de tomate. Plant Genet. Resources Nwsl. 124:7-12.

Pratta, G., R. Zorzoli, and L.A. Picardi. 2003. Diallel analysis of production traits among domestic, exotic and mutant germplasms of Lycopersicon. Genet. Mol. Res. 2:206-213.

Rick, C.M. 1979. Biosystematic studies in Lycopersicon and closely related species of Solanum, p. 667-678. In: J.G. Hawkes, R.N. Lester, and A.D. Skelding (eds.). The biology and taxonomy of the Solanaceae. Academic, New York.

Schuelter, A.R., F.L. Finger, V.W.D. Casali, S.H Brommonschenkel, and W.C Otoni. 2002. Inheritance and genetic linkage analysis of a firm- ripening tomato mutant. Plant Breeding 121:338-342.

Shapiro, S.S. and M.B. Wilk. 1965. An analysis of variance test for normality (complete samples). Biometrika 52:591-611.

Sokal, R. and F. Rohlf. 1969. Biometry. Freeman, San Francisco.

Tanksley, S.D. and S.R. McCouch. 1997. Seed banks and molecular maps: Unlocking genetic potential from the wild. Science 277:1063-1066.

Thompson, A.J., M. Tor, C.S. Barry, J. Vrebalov, C. Orfila, M.C. Jarvis, J.J. Giovannoni, D. Grierson, and G.B. Seymour. 1999. Molecular and genetic characterization of a novel pleiotropic tomato-ripening mutant. Plant Physiol. 120:383-389.

Weller, J.I., M. Soller, and T. Brody. 1988. Linkage analysis of quantitative traits in an interspecific cross of tomato (Lycopersicon esculentum $\mathrm{x}$ Lycopersicon pimpinellifolium) by means of genetic markers. Genetics 118:329 -339.

Zorzoli, R., G. Pratta, and L.A. Picardi. 1998. Efecto de los mutantes nor y rin y de genes silvestres sobre características del fruto en $\mathrm{Lyco}$ persicon. Mendeliana 13:12-19.

Zorzoli, R., G. Pratta, and L.A. Picardi. 2000. Variabilidad para la vida postcosecha yel peso de los frutos en tomate para familias $\mathrm{F}_{3}$ de un híbrido interespecífico. Pesquisa Agropecuaria Brasileira 35:2423-2427. 